University of Nebraska - Lincoln

DigitalCommons@University of Nebraska - Lincoln

June 1984

\title{
The Presidential Political Business Cycle of 1972
}

Robert R. Keller

University of Nebraska - Lincoln

Ann Mari May

University of Nebraska - Lincoln, amay1@UNL.edu

Follow this and additional works at: https://digitalcommons.unl.edu/cbafacpub

Part of the Business Commons

Keller, Robert R. and May, Ann Mari, "The Presidential Political Business Cycle of 1972" (1984). College of Business Faculty Publications. 25.

https://digitalcommons.unl.edu/cbafacpub/25

This Article is brought to you for free and open access by the Business, College of at DigitalCommons@University of Nebraska - Lincoln. It has been accepted for inclusion in College of Business Faculty Publications by an authorized administrator of DigitalCommons@University of Nebraska - Lincoln. 


\title{
The Presidential Political Business Cycle of 1972
}

\author{
Robert R. Keller and AnN Mari May
}

Previous studies of the political business cycle have examined time series data to determine whether a pattern of pre-election boom and post-election slump exists. The studies do not investigate the behavior and mechanisms by which a politician may effectuate a political business cycle. We focus on one time period, 1969 to 1972, and conclude that President Nixon's personality and operating environment explain why he manipulated the economy for political gain. The mechanisms he utilized to improve macroeconomic conditions before the 1972 election include monetary policy, fiscal policy, and wage-price controls.

$\mathbf{T}$

HE public choice literature on political business cycles argues that self-interested politicians manipulate the economy for political gain. The literature supposes that a pattern emerges within an incumbent party's term in office where there is "relative austerity in early years" and a "potlatch right before elections." The hypothesis is tested by examining time series data over many decades to determine whether macroeconomic conditions improve before the election and deteriorate after the election. The orthodox literature has found substantial, but not conclusive, evidence to support the existence of the political business cycle. $^{2}$

The orthodox view is underdeveloped because it is narrowly focused on testing for the existence of pre-election booms and post-election slumps. The problem is that it does not "examine whether the government tries to manipulate the economy to achieve pre-electoral boom and post-electoral contraction but whether economic conditions actually do correspond to this pattern." ${ }^{3}$ Thus, the public choice literature uses a

Journal of Economic History, Vol. XLIV, No. 2 (June 1984). (C) The Economic History Association. All rights reserved. ISSN 0022-0507.

Robert R. Keller is a professor and Ann Mari May is a graduate student in the Department of Economics, Colorado State University, Ft. Collins, Colorado 80523. The order of the authors is listed alphabetically. They would like to thank members of the rational choice seminar at Colorado State, especially Paul R. Brace, and the discussant at the Economic History Association Annual Meeting, Peter D. McClelland, for many constructive comments on an earlier and longer version of this article.

1 William Nordhaus, "The Political Business Cycle," Review of Economic Studies, 52 (April 1975), 1969-90.

${ }^{2}$ Ryan C. Amacher et al., "The Political Business Cycle: A Review of Theoretical and Empirical Evidence," Association for Comparative Economic Systems Bulletin (Fall/Winter 1979), 1-42; and Nathaniel Beck, "Does There Exist a Political Business Cycle: A Box-Tiao Analysis," Public Choice, 37, no. 2 (1982), 205-9.

${ }^{3}$ Kristen R. Monroe, "Political Manipulation of the Economy: A Closer Look at Political Business Cycles," Presidential Studies Quarterly, 13 (Winter 1983), 37-49. 
method that emphasizes prediction and correlation at the expense of explanation and causation. ${ }^{4}$

Our research is motivated by the failure of most previous studies to provide a detailed analysis of the role of the president in the political business cycle. We argue that the personality and operating environment of the president determine whether he will manipulate the economy for political gain. The years 1969 to 1972 were chosen because several studies intimate that Richard Nixon effectuated a political business cycle. ${ }^{5}$

\section{THE CONCEPTUAL FRAMEWORK}

Public choice models of the political business cycle in the United States posit a national decision maker, the president, and assume that he is rational, self-interested, and inclined to use macroeconomic policies to maximize his or his party's plurality in the upcoming election. ${ }^{6}$ We assume that the president's personality and operating environment determine whether he will implement macroeconomic policies to manipulate the economy for political gain. The existence of a political business cycle reflects, in part, particular motives manifested in the president's behavior. As James Barber emphasizes, the president's personality, especially character, is an enduring orientation that contributes to the shaping of his world view and style. ${ }^{7}$ For example, Barber's "active-negative" personality type closely conforms to the behavioral assumptions of a self-interested, vote-maximizing politician. The active-negative is a man for whom " 'principles' are more important as rationalizations justifying behavior than guides for choice." ${ }^{\prime 8}$ The active-negative has an aggressive approach to problems and a need to manipulate and control outcomes.

The president's decision to manipulate the economy for political gain is influenced by the operating environment, which includes the importance of the election, the president's motivation and the perceived outcome of the election, the probability of detection, and the perceived importance of macroeconomic performance. According to Tufte, election years can be ordered from maximum to minimum electoral impor-

\footnotetext{
${ }^{4}$ Mark Blaug, The Methodology of Economics (Cambridge, 1980), pp. 1-9.

${ }^{5}$ Edward Tufte, Political Control of the Economy (Princeton, 1978); and Nordhaus, "The Political Business Cycle."

${ }^{6}$ For a discussion of rationality, see Anthony Downs, An Economic Theory of Democracy (New York, 1957), pp. 4-11; Amacher, "The Political Business Cycle."

${ }^{7}$ James D. Barber, The Presidential Character: Predicting Performance in the White House (Englewood Cliffs, New Jersey, 1977, 1972). For a critique of Barber's typology of political leaders, refer to Alexander L. George, "Assessing Presidential Character," in Perspectives on the Presidency, ed. Aaron Wildausky (Boston, 1975), pp. 91-134.

${ }^{8}$ Barber, The Presidential Character, p. 353.
} 
tance in the following manner: on-year, incumbent president seeking reelection; mid-term, congressional elections; on-year, incumbent president not seeking reelection; and odd-numbered years. ${ }^{9}$ Tufte says: "There are surely special incentives to the administration in those onyears when the incumbent president seeks reelection; his direct personal interest in political survival coincides with what must be a particularly tempting opportunity to hit the economic accelerator." 10 If a selfinterested president perceives that he will lose an election or that his vote share will be too small, then he may attempt to manipulate the economy for political gain. We assume that the president's perception of the election outcome is obtained by data from public opinion polls on economic issues and policies, and the president's popularity. The president's decision to manipulate the economy is constrained by the ideology of his opposition. For example, if the opposition is more liberal than the incumbent, criticism for excessive spending will be less likely. Finally, the president must be convinced that favorable or improving economic conditions will have a positive impact on his reelection prospects.

The conceptual framework is represented by iso-vote (vote share) curves and Phillips curves. ${ }^{11}$ The iso-vote curves are concave with respect to the origin and in the same space as the conventional Phillips curve. The president's vote share increases with lower inflation or lower unemployment. The state of the economy is represented by a point on a short-run Phillips curve. If the president wants to increase his vote share then he may implement policies that cause a movement along the Phillips curve, an inward shift of the Phillips curve, or an outward shift of the iso-vote curves.

\section{NIXON'S POLITICAL BUSINESS CYCLE}

The political business cycle in the years 1969 to 1972 reflects Nixon's ideology, personality, operating environment, and macroeconomic policies.

\section{The President's Behavior and Operating Environment}

According to Barber, Nixon was self-interested, his ideology and principles were flexible, and his stance toward the political environment was aggressive. ${ }^{12} \mathrm{He}$ believed that macroeconomic variables were important in determining election outcomes. He blamed the economy for Republican losses in 1954 and 1958, and he was forever convinced

\footnotetext{
${ }^{9}$ Tufte, Political Control of the Economy, p. 23.

${ }^{10}$ Ibid.

" For a similar approach, refer to Kevin J. Maloney and Michael L. Smirlock, "Business Cycles and the Political Process,"' Southern Economic Journal, 48 (Oct. 1981), 377-92.

${ }^{12}$ Barber, The Presidential Character, pp. 409, 441-42.
} 
that he lost the 1960 election because of the recessionary state of the economy. ${ }^{13}$ Nixon's concern about economic issues persisted through time. The White House tapes reveal that he continued to react "hyperpolitically to economic issues." ${ }^{14}$ Finally, Nixon was challenged within his own party by a liberal candidate, Paul McCloskey, and by liberal candidates of the opposing party-first, Muskie; later, McGovern. Thus, it was unlikely that these liberal candidates would accuse Nixon of excessively expanding the economy.

\section{The Mechanisms of Manipulation}

It is commonly asserted that a president will implement contractionary policies after an election to reduce inflation and inflationary expectations, setting the stage for expansion before the next election. We contend that the contractionary policies implemented after the 1968 election were consistent with the ideology of a conservative Republican president and do not reflect political manipulation. Inflation was viewed as a serious problem, and a good Republican president could be expected to implement contractionary policies. Dwight Eisenhower said: "I think Dick's going to be a one-term President. I think he's really going to fight inflation, and that will kill him politically." 15

In response to the contractionary monetary and fiscal policies of 1969 and 1970 the unemployment rate rose more than expected and inflation proved to be an intractable problem. Nixon faced a nightmare of recession and inflation. He told Republican leaders early in 1970 that if he could not bring the unemployment rate down below 5.5 percent, the Republicans would suffer losses in the mid-term elections. ${ }^{16} \mathrm{He}$ was right. Nixon's concerns were amplified by public opinion polls that showed that the poor state of the economy was causing a decline in his popularity. ${ }^{17}$ The Gallup opinion poll showed Nixon's approval rating declining to 49 percent in April 1971. ${ }^{18}$ The Harris poll indicated that Muskie, the top Democratic rival at that time, was expanding his lead over Nixon until it reached a 47 percent to 39 percent margin in April $1971 .^{19}$

Although the Fed and its monetary policy is ostensibly independent from the president and politics, Sherman Maisel, a former governor of the Federal Reserve Board, has remarked that the executive branch

\footnotetext{
${ }^{13}$ Richard M. Nixon, Six Crises (New York, 1968), pp. 333-34.

${ }^{14}$ Leonard Silk, 'Tapes' Insight on Nixon: They Indicate His Economic Thinking is Heavily Weighted by Political Factors,"' New York Times, Aug. 7, 1974, p. 47.

${ }^{15}$ Rowland Evans, Jr., and Robert D. Novak, Nixon in the White House (New York, 1971), p. 178.

${ }^{16}$ Theodore White, The Making of the President, 1972 (New York, 1973), p. 62.

${ }^{17}$ Michael Wheeler, Lies, Damn Lies, and Statistics: The Manipulation of Public Opinion in America (New York, 1976), pp. 11-12.

${ }^{18}$ White, The Making of the President, 1972, p. 59.

19 Ibid.
} 
exerts a powerful influence over the Fed. ${ }^{20}$ The chairman of the Board of Governors wields the most power within the internal structure of the Fed. ${ }^{21} \mathrm{~A}$ close alliance between the president and the chairman may imply an even stronger influence by the executive branch over the Fed. Nixon clearly viewed monetary policy as an integral part of his economic policies. John Ehrlichman notes that "Nixon was determined to control the Fed while maintaining the image of its independence from all politicians, including himself." 22 Nixon, himself, said to Burns, "I know there's a myth of the autonomous Fed . . . and when you go up for confirmation some Senator may ask you about your friendship with the President. Appearances are going to be important, so you can call Ehrlichman to get messages to me, and he'll call you.,"23

It is quite clear that Nixon desperately wanted the Fed to implement expansionary policies to reduce unemployment. Nixon's motivation for urging an expansionary monetary policy was political. There is reason to believe that the Fed was either pressured politically or politically motivated to expand the money supply because Nixon appointed Burns as chairman of the Fed, Nixon and Burns were long-time associates, Nixon frequently demanded that Burns expand the money supply, and Burns understood the political implications of high unemployment. ${ }^{24}$ Although the Fed's motives are certainly debatable, the Fed's policy was expansive, some say much too expansive, from 1970 to $1972 .{ }^{25}$ The quarterly growth in the money supply averaged slightly more than 7 percent per year from the second quarter of 1970 to the end of $1972 .{ }^{26}$ From Blinder's estimates the expansion of the money supply above its trend rate of growth added approximately $\$ 51$ billion (1958 dollars) to real GNP in the year before the election. ${ }^{27}$

Turning to Nixon's use of fiscal policy for political gain, it is important to distinguish between the aggregated and disaggregated effects of policy. Fiscal policy has an impact on national aggregates such as disposable income, spending, and production. ${ }^{28}$ It also has disaggregated impacts because policies can be used to target spending or taxes to particular groups in various regions of the country.

\footnotetext{
${ }^{20}$ Sherman Maisel, Managing the Dollar (New York, 1973), pp. 108-13.

${ }^{21}$ Ibid. Another insider states: "The discussion will associate monetary policy with Arthur Burns, because for all intents and purposes monetary policy was Burns." James L. Pierce, "The Political Economy of Arthur Burns," Journal of Finance, 34 (May 1979), 485.

22 John Ehrlichman, Witness to Power (New York, 1982), p. 244.

23 Ibid., p. 248.

${ }^{24}$ Ehrlichman notes that "Burns was every bit as much a politician as he was an economist." In Ehrlichman, Witness to Power, p. 244.

${ }^{25}$ Pierce, "The Political Economy," p. 495.

${ }^{26}$ Alan Blinder, Economic Policy and the Great Stagflation (New York, 1979), p. 33.

27 Ibid., p. 34.

${ }^{28}$ The orthodox literature investigates the existence of the political business cycle by correlating the performance of economic aggregates such as unemployment and disposable income with voting behavior. See Ray C. Fair, "The Effect of Economic Events on Votes for President," Review of Economics and Statistics, 50 (May 1978), 159-73.
} 
Tufte is convinced that the fiscal expansion was a reflection of political motivation. ${ }^{29}$ Blinder, although more cautious, is at least "tempted" to blame the fiscal expansion on the proximity of the election. ${ }^{30}$ The aggregate impact of fiscal expansion between mid-1971 and the end of 1972 was "the highest in the entire 1959-1973 period.",31 The effect of expansionary fiscal policy of 1971 and 1972 was to add $\$ 63.6$ billion (1958 dollars) to real GNP and to increase the growth rate of GNP from 4.7 percent to 7.3 percent in the four quarters before the election. ${ }^{32}$

There is more direct evidence of Nixon relying on the disaggregated impact of fiscal policy for political purposes. An appropriate starting point is the White House's "Responsiveness Program." The program in general made departments and agencies of the federal government responsive to Nixon's reelection needs. More specifically, it used government resources in the form of personnel, loans, grants, contracts, appointments, and brochures to target swing voters such as blacks, Hispanics, and the elderly in key states. ${ }^{33}$ The same strategy is evident in a number of government spending and tax programs. Nixon was aware of target voters in key states who could swing the election in his favor and he used social security benefits, veteran benefits, and grantsin-aid to state and local governments to influence voters. ${ }^{34}$

In August 1971, wage-price controls were implemented by a conservative president historically opposed to any form of controls. Nixon's opposition to wage-price controls was largely based on ideology and bitter memories of his days in the Office of Price Administration. Nevertheless, Nixon imposed controls for the following reasons. First, the problem of inflation was intractable: it averaged nearly $4 \frac{1}{2}$ percent per year in the first half of 1971. Second, public opinion polls indicated that voters considered inflation to be a serious problem. ${ }^{35}$ Third, the public was in favor of controls. In November 1970, 65 percent of those polled favored the government setting wage-price controls. ${ }^{36}$ In June 1971, Gallup public opinion poll data showed that 50 percent favored an outright freeze on wages and prices while 39 percent opposed it. ${ }^{37}$

There is evidence indicating that wage-price controls shifted the Phillips curve inward. Blinder estimates that controls reduced inflation,

\footnotetext{
29 Tufte, Political Control of the Economy, pp. 45-55.

${ }^{30}$ Blinder, Economic Policy, p. 32.

31 Ibid., p. 145.

32 Ibid.

${ }^{33}$ Refer to: Presidential Campaign Activities of 1972, Watergate and Related Activities: Use of Incumbency-Responsiveness Program (Washington, D.C., 1974), Books 18 and 19.

${ }^{34}$ Tufte, Political Control of the Economy.

${ }^{35}$ Wheeler, Lies, p. 11. Wheeler talks about the impact that Sindlinger and his poll had on the White House. Also see Gallup Opinion Index, July 1971, Report No. 73, p. 17.

${ }^{36}$ Blinder, Economic Policy, p. 111.

${ }^{37}$ Gallup Opinion Index, Aug. 1971, Report No. 74, p. 6.
} 
increased output, and reduced unemployment from the time they were imposed to well past the election. ${ }^{38}$ Moreover, the public's reaction to Nixon's new policies was very positive, which may imply an outward shift of the president's vote share curves. One week after the imposition of controls, the Gallup Poll indicated that 73 percent had a favorable reaction, 16 percent had an unfavorable reaction, and 11 percent had no reaction to Nixon's announced policies of August 15, 1971. ${ }^{39}$

\section{CONCLUSION}

Nixon's manipulation of the economy resulted from a particular constellation of factors. First, Nixon's personality closely conforms to the behavioral assumptions of the public choice literature on the political business cycle. Nixon appears to be the epitome of the selfinterested, pragmatic, politically astute, active president who would be most likely to manipulate the economy for political gain. He also had a chameleon-like quality with respect to rationalizing economic policies. In 1969 he subscribed to monetarism and gradualism, in January 1971 he proclaimed himself a Keynesian in economics, and by mid-1971, with the enactment of wage-price controls, he could be labeled a postKeynesian. Further, he was extremely sensitive to the importance of macroeconomic variables affecting election outcomes. And, his operating environment provided few constraints and ample opportunity for effectuating a political business cycle.

In contrast to previous studies, we believe the contraction phase of the political business cycle reflects ideological concerns and that it is only the expansion phase that demonstrates political manipulation. The means by which Nixon manipulated the economy include monetary policy, fiscal policy, and wage-price controls. In the expansion phase, we place great emphasis on monetary policy and wage-price controls. The evidence is fully consistent with studies that conclude that "monetary policy has responded to the political goals of specific Presidents.",40 The failure of the literature to examine wage-price controls as a policy option is a serious oversight-it is the one policy unambiguously implemented by the President, and it represents a consummate attempt to manipulate the inflation and unemployment trade-off for political gain.

\footnotetext{
38 Blinder, Economic Policy, p. 27.

${ }^{39}$ Gallup Public Opinion Index, Sept. 1971, Report No. 75, p. 3.

${ }^{40}$ Maloney and Smirlock, “Business Cycles,'” p. 389.
} 